\title{
Coverage of Black versus White Males in Local Television News Lead Stories
}

Trina T Creighton ${ }^{1 *}$, Curtis L Walker ${ }^{2}$ and Mark R Anderson ${ }^{3}$

${ }^{1}$ College of Journalism and Mass Communications, University of Nebraska-Lincoln, USA

${ }^{2}$ Department of Earth and Atmospheric Science, University of Nebraska-Lincoln, USA

${ }^{3}$ Department of Earth and Atmospheric Science, University of Nebraska-Lincoln, USA

\begin{abstract}
As far back as the early 1990s scholars have analyzed how some television news stations have disproportionately portrayed Black males as notorious lawbreakers, while White males are significantly more likely to be depicted as heroes, defenders of all that is righteous, or the perpetual "good guys." As a result of those early articles many other researchers have examined the prevalence of such reporting as well as the impact it has on Black males as well as society. Most of those studies have focused on the entire newscasts coverage of big city television markets, like Chicago or New York. No study has performed a similar analysis on the lead news story. Nebraska has recently been designated as the "most dangerous place in America to be Black." Nebraska received that title even though it has an extremely small Black population, $4.8 \%$, most of whom live in Omaha, the state's largest city. This research looks at how Omaha's four local television network affiliates-ABC, CBS, NBC and Fox-portray Black males versus White males in their lead or first stories of their newscasts. A team of coders evaluated three-months of newscasts from each station. The statistical findings are clear: crime-related stories account for more than $60 \%$ of lead news stories in Omaha, and Black males were featured in the primary crime story subject nearly $70 \%$ of the time even though crime statistics show that Blacks are only responsible for $31 \%$ of arrests during the same 3-month period.
\end{abstract}

Keywords: Black males in media; Crime and media; Lead news story; Media bias; Media framing; Media portrayal; White males in media

\section{Introduction}

The slogan "If it bleeds, it leads" is well known in the television industry as local news broadcasts dramatic images of violence, dead bodies, gunfights, and overall suffering. Omaha's population is more than 400,000 and this television market was selected because of its proximity to the researchers and the fact that the city of Omaha has recently been named as "the most dangerous place in America to be Black" [1]. The Violence Policy Center (VPC), a Washington, D.C.based research and advocacy group that promotes gun control, found in 2011 that there were 30 Blacks murdered in Nebraska, 27 of those homicides were in Omaha, most of those deaths were in the Black community often referred to as "North Omaha." That puts Nebraska's Black homicide rate at 34.4 per 100,000 per capital, which is double the national average of Black victimization [1]. When Nebraska was ranked in the VPC study in 2009 it was in $11^{\text {th }}$ place, in just two years it had jumped to the No. 1 position.

The U.S. Census Bureau in 2012 figured that Blacks account for 13.1 percent of the American population. Less than $5 \%$ of Nebraska's population is of Black Americans (4.8\%), most of whom live in the state's largest city, Omaha, with $13.7 \%$ of the city's population identified as Black Americans [2]. Of the 30 murders in 2011, 90\% of deaths were in Omaha neighborhoods with more than 75\% Black population [1]. Also, while the state of Nebraska has one of the lowest jobless rates in the country, at a little more than $4 \%$, a 2004 state-bystate unemployment check for Black males found that more than $27 \%$ of Black males living in Nebraska were unemployed [3].

Previous research [4-11] has examined how some television news programs disproportionately portray Black males, as lawbreakers, while White males are significantly more likely to be shown in the context of a defender, or the "good guy." However, there is no known work that has focused solely on media bias associated with the lead news story in local newscasts. When Black males are frequently featured as lawbreakers/troublemakers it reinforces the stereotype that Blacks are responsible for the most crime [12]. How media portray crime, the extent of the crime problem and who is responsible for crime may shape public opinion. If a specific group (Black males or other people of color) is over- or underrepresented in news media as perpetrators or victims of crime, audiences may form racial and or gender stereotypes or develop hostility toward such groups [13]. This study examines the portrayals of Black versus White males in the lead news stories of four Omaha television network affiliates-KETV (ABC), WOWT (NBC), KMTV (CBS), FOX42 (FOX) over a three-month. Only those news stories about either a single or group of Black or White male(s) were considered and other ethnic groups, or groups of multiple ethnicities, were omitted from this analysis. The goal of this research is to show which male group is represented more often in the lead story and how this representation relates to the actual police reported crime data for the same period. Frequent news viewers understand and expect the first story in a newscast to be the most important story of the day. Currently the research is not showing any study that has focused solely on a television stations lead news story. Lead stories are more powerful than other stories in a newscast and help shape public perceptions [14]. In fact, the more the news outlets play up a story the more affect it has on public opinion [14].

*Corresponding author: Trina T Creighton, 240 Andersen Hall, College of Journalism and Mass Communications, University of Nebraska-Lincoln Lincoln, Nebraska, USA, Tel: 402-208-9128; E-mail: tcreighton2@unl.edu

Received August 04, 2014; Accepted September 09, 2014; Published September 17, 2014

Citation: Creighton TT, Walker CL, Anderson MR (2014) Coverage of Black versus White Males in Local Television News Lead Stories. J Mass Communicat Journalism 4: 216. doi:10.4172/2165-7912.1000216

Copyright: (c) 2014 Creighton TT, et al. This is an open-access article distributed under the terms of the Creative Commons Attribution License, which permits unrestricted use, distribution, and reproduction in any medium, provided the original author and source are credited. 


\section{Literature Review}

Studies from as far back as the late 1970's have suggested, "Crime stories in the news may shape public conception of order and justice in the community," [12,15,16]. Dixon and Linz [12] equate the way television news portrays crime as "a modern play" in which the "devil" is both symbolically and physically cast out from the society by "guardians-police and the judiciary." Other researchers [17] theorized that the perpetrators of crime, who according to the images shown during local newscasts appear to be overwhelmingly Black males, begin to represent the "evil forces" in society that must be controlled to maintain social order. Chiricos and Eschholz [7] suggests local TV news may contribute to social controls and exclusions in relation to Blacks and Hispanics, a condition associated with the fear of crime identified as "modern racism." Furthermore, "modern racism," is defined as a form of racism that is more subtle but perhaps more harmful in the long run [8-11], and can be characterized as "anti-black affect or a general hostility toward Blacks" [11]. Today's media's representation of Blacks and race leads to two different but closely related views: "[T]he first assumes that crime is stereotypically portrayed as a Black phenomenon, and the second assumes that Blacks are disproportionately portrayed as criminals" [7]. The implications of connecting Blacks, especially Black males with crime is well documented and some researchers believe that link may've been solidified during the 1988 Presidential election race between George Bush and Michael Dukakis, when the Bush campaign unveiled the infamous Willie Horton photo. Even though it has been more than 25 years since Horton's face was splashed across television screens into American homes, his image may still be what researchers call the iconography of Black criminal threat so much so that Horton has led to the assertion that "today's prevailing criminal predator has become a euphemism for young Black male" [10].

When it comes to crime, news outlets, on the other hand, tend to show White adults in much more positive roles compared to Blacks [18]. Whites are overrepresented as police officers when employment records do not support that representation [18]. Local news, with its typically heavy focus on urban crime, may have some responsibility for this exaggerated perception [19].

The emphasis on crime in local television news does not appear to be fueled by the public's curiosity. According to Behr [20], it is not public concern that influences television news coverage. On the contrary, it is what television news managers chose to cover. Even though news viewers have many choices to receive information; "television remains the dominant way that Americans get news at home" [21]. Seventy-one percent of people seeking news watch it on local television stations [22].

Barlow et al. [17] suggested that when television newscasts frequently overrepresented certain groups, like males and people of color as perpetrators and overrepresented [7] other groups, like females and Whites as victims, they may mislead the public to view incorrectly certain groups as the most vulnerable to crime and other groups as always the villains Dixon and Linz [12] and Russell [23] suggested that media sources can shape public opinion that could lead to disproportionate criminal penalties for crimes that are more typically committed by those groups that are overrepresented as lawbreakers in news stories. Over the past two decades penalties toward criminals have resulted in a tripling of incarcerations rates, despite the fact that crime is leveling off and in some cases falling [24,25]. This may be occurring because crime is thought to be a Black male phenomenon [26]. The disparities in sentences for possession of crack cocaine versus powdered cocaine, for example, has been attributed to the well documented fact that $90 \%$ of federal prosecution for crack-cocaine involves black defendants compared to about $30 \%$ of White males who use powdered cocaine $[24,25,27]$.

Entman [5] may be among the first researchers to suggest that crime is often covered in news stories, and when compared to Whites, Blacks are more likely to be shown as perpetrators and less as sympathetic victims. Dixon and Linz [12,28], focused on the [26] inaccuracies of crime coverage on local television news by showing that minorities were overrepresented as criminals when compared to Whites than what actual crime statistics indicated. In fact, not only were Blacks overrepresented as law breakers but they were also depicted in more negative ways. While most studies of this nature focused on single-market samples, Bjornstrom et al. [29] based their analysis on a national sample of local news stories. Bjornstrom et al. [29] also suggested "such a relative over reporting of Black offenders' accords with the predictions of power structure, racial threat, and privileging explanations...." The Bjornstrom et al. [29] study revealed that the way news stations present stories is often based on what the researcher refers to as "racial privilege," which leads to news outlets to pay greater attention to the victimization of Whites than non-Whites. Bjornstrom et al. [29] contend this imbalance flows from the fact the majority of media are owned and managed by Whites and they (owners and managers) are more interested in presenting news about White victims than minorities. Therefore the frequent reporting of Blacks as predators "may be a case of media reflecting dominant groups' views through delegitimizing Blacks by portraying them as criminal."

Black males are among the most misunderstood groups in America, they are often perceived and stereotyped by the five D's: dumb, deprived, dangerous, deviant and disturbed [30]. In every area considered an indication of success, Black males are failing and obviously in peril [31]. Black young men are incarcerated at a disproportionate rate. They represent a disproportionate number of the unemployed. They drop out of school more than any other group. They are suspended from school more frequently; expelled more often; score more poorly on tests; and more often are placed in special education than students from other groups [32]. And for the past two decades, Black males are the only segment of the population in America whose life expectancy is declining [33,34].

Some research suggests that when Black boys see themselves regularly in the news as lawbreakers, those images may have a negative effect by causing a self-fulfilling prophesy [35]. The way Black males are portrayed in the news can affect a Black boy's self-perception [35] According to The Opportunity Agenda [36], an organization formed in 2006 to expand opportunities for everyone living in America, this misrepresentation of Black males in local news coverage not only negatively influences public opinion about Black men in general, it sometimes negatively affects the understandings and attitudes of the Black males toward themselves.

Blacks also are more likely to be portrayed in local newscast as ruthless lawbreakers [5]. Entman [5] also found that for every White adult that a television newscast showed being restrained by police officers there were more than twice as many Blacks shown in a similar predicament Prior studies and research that suggest newscast gathering and dissemination practices tend to characterize Blacks as criminals more often than Whites who are shown as the savior or rescuer.

It has been well documented in research that local newscasts misrepresent Blacks as the racial group that is committing most crime $[5,6,12]$. In one study, researchers, Dixon and Linz [12] suggest that despite arrest records to the contrary, "Blacks were twice as likely as 
Whites to be portrayed as perpetrators, six times more likely to be portrayed as perpetrators than as officers, and overrepresented as criminals $37 \%$ of the time while comprising only $21 \%$ of those arrested according to crime reports. "Almost nightly, local newscasts by their selection of the night's "lead" story, portray urban America as out of control and Blacks as being responsible [19,37]. This negative portrayal of Black males has been going on for decades. In 1993 a yearlong study was launched of local Chicago television newscasts. It found that news stories about Blacks were four times more likely to include mug shots than stories about Whites accused of crimes [38].

\section{Methodology}

A content analysis of Omaha's four local television affiliates was compiled using a sample of their late evening, 9 or 10 p.m. local time, newscasts. The broadcasts studied were recorded Sunday through Saturday newscasts for a period of three-months: September, October, and November 2012. Data were collected from a total of 364 newscasts. The newscasts were converted to a Web format that could be accessed by computer. The data coding process was conducted by having five coders watch only the first/lead story of every newscast. More than $50 \%$ of the lead stories were viewed by an assistant professor of practice. The lead author of this article watched and coded every story. The lead author of this article watched and verified the coding for every story. The coder's findings are consistent.

For the purpose of this study, only the lead news stories with either a Black or White male subject were considered. Lead stories in which the primary ethnicity could not be determined, ethnicities other than Black/White, or those that had multiple ethnic groups were not included in the analysis. Lead news stories with female subjects were excluded from the analysis regardless of ethnicity. Similarly, lead stories that were not about people but rather animals (e.g., mountain lions) were also not included. The majority of the lead stories removed focused on more local/national news stories that discussed multiple ethnicities. Examples of the stories removed include those that discussed the impacts of Hurricane Sandy in October 2012, the presidential election of November 2012, Nebraska's popular football team (the Huskers), and holiday shopping, all of which were not ethnic or gender specific. An important caveat to note is that a lead story that focused on either a single Black or White male would be included in the analysis. Stories were not omitted on the basis of story topic. For example, a lead story about only the President (Barack Obama, who is Black) would be included despite its being about the presidential election.

For ease of use, the stories used in the analysis were grouped in five primary categories: Accident, Crime, Local, Nationwide and Sports. Accident lead stories tended to be those about some type of vehicular crash or workplace incident. Crime lead stories featured some type of law-breaking activity or a follow-up to a previous crime. Local news stories included those about an event, other than a crime or accident, occurring in the Omaha metropolitan area such as a house fire. Nationwide stories were those that pertained to events such as the September $11^{\text {th }}$ Anniversary or the Presidential Election. Sports stories were those typically dominated by individuals associated with Nebraska sports. Table 1 provides the number of individual news stories that were coded and how they were sorted among the five primary groups.

Portrayal of the primary story subject was coded with a five-point scale, with one being highly negative and five being highly positive. Portrayals scored as one or two were combined to represent a negative portrayal. A negative portrayal was designated when the principal male in the lead story was accused of a crime, arrested, sought by law enforcement, incarcerated, sentenced to serve time, or was a victim of a crime. Portrayals scored as four or five were similarly combined to represent a positive portrayal. A positive portrayal was defined when the principal male in the lead story was featured as saving lives, spreading goodwill, committing good deeds, improving others/community or his situation in life. A portrayal of three represented a neutral portrayal.

A correspondence analysis [39] was performed on the entire data set in order to statistically determine which combinations of factors (i.e., story subject portrayal, story subject ethnicity, and story subject category) would be grouped together. These groups were then analyzed to determine whether they agreed with the findings of the content analysis and previous literature.

\section{Results}

\section{Comparison of black versus white males}

September 2012 had 101 total lead news stories that satisfied the criteria of a Black or White male only story (Figure 1 and Table 1). Of those, $57 \%$ (58 stories) had a lead story subject of a Black male, with the remaining $43 \%$ ( 43 stories) had a White male as the subject. Of those 101 news stories in the month of September, 67\% (68 stories) were associated with criminal activity. A majority of those crime-related stories, $75 \%$ (51 stories), had a Black male as the primary story subject.

In comparison, October 2012 had only 50 total lead stories which satisfied the criteria. In terms of story subject ethnicity, October 2012 had an equal number (25 stories each) that contained either a Black or White male as the lead story subject. Of those 50 lead stories in October that satisfied the criteria, 66\% (33 stories) were crime-related (Figure 1 and Table 1). It is important to note that despite the difference in total lead news stories between September and October, the percentage of crime-related lead stories remains nearly consistent. Of the 33 crime-

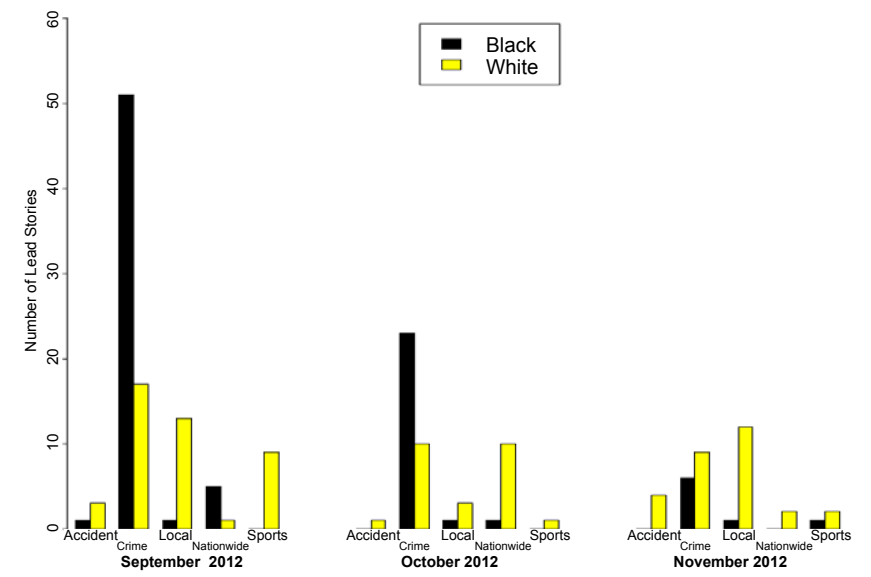

Figure 1: September 2012 through November 2012 lead news story distribution by topic category and story subject ethnicity. The black bars correspond to lead news stories with a Black male as the primary story subject and the yellow bars represent lead news stories with a White male.

\begin{tabular}{|l|c|c|c|c|c|c|}
\hline Month & Accident & Crime & Local & Nationwide & Sports & Total \\
\hline September & 4 & 68 & 14 & 6 & 9 & $\mathbf{1 0 1}$ \\
\hline October & 1 & 33 & 4 & 11 & 1 & $\mathbf{5 0}$ \\
\hline November & 4 & 15 & 13 & 2 & 3 & $\mathbf{3 7}$ \\
\hline Total & $\mathbf{9}$ & $\mathbf{1 1 6}$ & $\mathbf{3 1}$ & $\mathbf{1 9}$ & $\mathbf{1 3}$ & $\mathbf{1 8 8}$ \\
\hline
\end{tabular}

Table 1: Distribution of lead news stories for September through November 2012 by topic categories. 
related lead stories, $70 \%$ ( 23 stories) had a Black male as the primary perpetrator of the crime compared to $30 \%$ (10 stories) with a White male perpetrator.

November 2012 appeared to be an outlier month in comparison to the previous two. This is likely due to the increased lead story media coverage of both the November 2012 presidential election as well as continuing news coverage of Hurricane Sandy that had recently impacted several cities along the East Coast. November 2012 had 37 lead stories that satisfied the criteria of which $22 \%$ (8 stories) focused on Black males and the remaining 78\% (29 stories) focused on White males. Crime-related stories accounted for only $41 \%$ (15 stories) of all lead stories during this month (Figure 1 and Table 1). November 2012 also was the only month in this sample in which more crime-related lead stories focused on White rather than Black males. Black males accounted for $40 \%$ (6 stories) of crime-related lead stories compared to the remaining $60 \%$ (9 stories) that had a White male as the primary perpetrator. Overall, the month of November had the fewest crimerelated lead news stories, and those lead crime stories that aired happened to involved more White than Black males.

Considering all three months combined (Figure 2 and Table 1), there were 188 total lead news stories that satisfied the criteria. Of lead stories, there was a nearly even division between the two ethnic groups; 49\% (92 stories) pertained to Black males and 51\% (96 stories) pertained to White males. Crime-related news stories remained the most frequent with $62 \%$ (117 stories) of all lead stories during the period. Of those crime-related stories, $69 \%$ (81 stories) had a Black male as the perpetrator while $31 \%$ (36 stories) had a White male as the perpetrator. From these results it becomes clear that crimerelated stories constitute a major part of the lead stories in the Omaha television news market. This concurs with the previous literature that a majority of news stories do pertain to some type of criminal activity [4-6]. Further, many of these crime-related stories portray Black males as the primary perpetrator of crime.

Obviously the lead story does not cover every single crime; however, the disproportionate representation of Black males as perpetrators does suggest that more crimes are committed by Blacks rather than

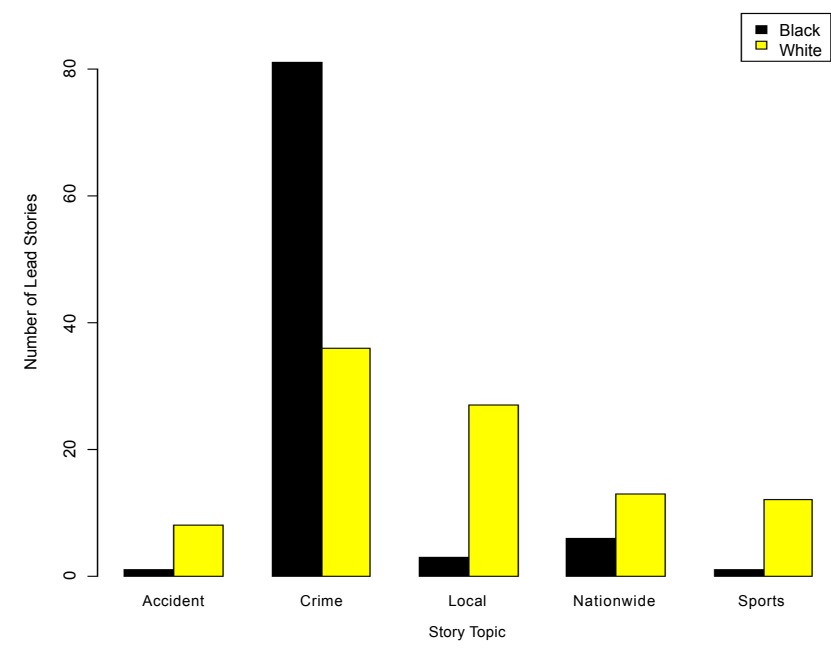

Figure 2: September 2012 through November 2012 combined lead news story distribution by topic category and story subject ethnicity. The black bars correspond to lead news stories with a Black male as the primary story subject and the yellow bars represent lead news stories with a White male.

\begin{tabular}{|l|c|c|c|}
\hline Month & White & Black & Total \\
\hline September & 1166 & 751 & 1917 \\
\hline October & 1042 & 685 & 1727 \\
\hline November & 1135 & 689 & 1824 \\
\hline Total & 3343 & 2125 & 5468 \\
\hline
\end{tabular}

Table 2: Arrest Records from the Omaha Police Department in Douglas County for September through November in 2012 [44].

Whites. The actual arrest records (Table 2) show that in Omaha far more Whites (61\%) are arrested than Blacks (39\%). It should be noted that the arrest records are for the Omaha Police Department in Douglas County, where the majority of the Black population resides even though the lead story was not restricted to Douglas County. Offense data are specific to eight crimes: Homicide, Rape, Robbery, Assault, Burglary, Larceny, Motor Vehicle Theft, and Arson (Table 2). Given the population demographics of the Omaha media market, it is not unreasonable to expect that more Whites should be arrested than other ethnic groups. Though, as the analysis has shown, despite the arrest record data and population demographics, far more Black males become the subject of media attention for their crimes.

This study also reflects an interesting trend: Each month from September 2012 through November 2012 there is a decrease in the number of lead news stories pertaining to crime. An increasing body of literature $[40,41]$ discusses the relationship between temperatures and criminal activity. These studies suggest that crime rates are highest during warm weather and lowest in cold weather. The period during September through November typically is the transition from warm temperatures to cooler ones and these data do show a decreasing trend in crime-related lead news stories.

Despite being a minority of the Omaha population, Black males appeared more frequently than White males as perpetrators and felons as depicted in the lead story in local television newscasts. This was supported by the data set as a whole in addition to the individual months of September and October in 2012. November 2012 was the only month that deviated from the pattern, possibly due to increased lead story media coverage of the election.

\section{Correspondence Analysis}

A correspondence analysis was performed on the entire data set due to relatively small sample sizes within the lead story topic categories in order to obtain statistical relationships and patterns of groups pertaining to the lead news story subject ethnicity, portrayal and category variables. The correspondence analysis for the period was found to explain a substantial percentage, $92.5 \%$, of the statistical variability within the data set among the variables of story subject ethnicity, portrayal and topic category (Figure 3 ). The first eigenvalue (0.380) alone explained $86.5 \%$ of the variation among the data, while the second eigenvalue $(0.027)$ gave an additional $6.2 \%$ of variability explanation. The tight cluster (Cluster A) contains lead news stories with either Black males, negative portrayals or those that were crimerelated. Cluster A is important because it supports the content analysis findings that majority of the crime-related lead news stories had a Black male as the primary subject. It also concurs with the previous literature that many of these crime-related news stories with Black males are portrayed in a negative manner [4-6].

Cluster B contains lead news stories that either fell in the Nationwide or Accident categories, or those with neutral portrayals of the main story subject. These lead stories are similar in that they tended 


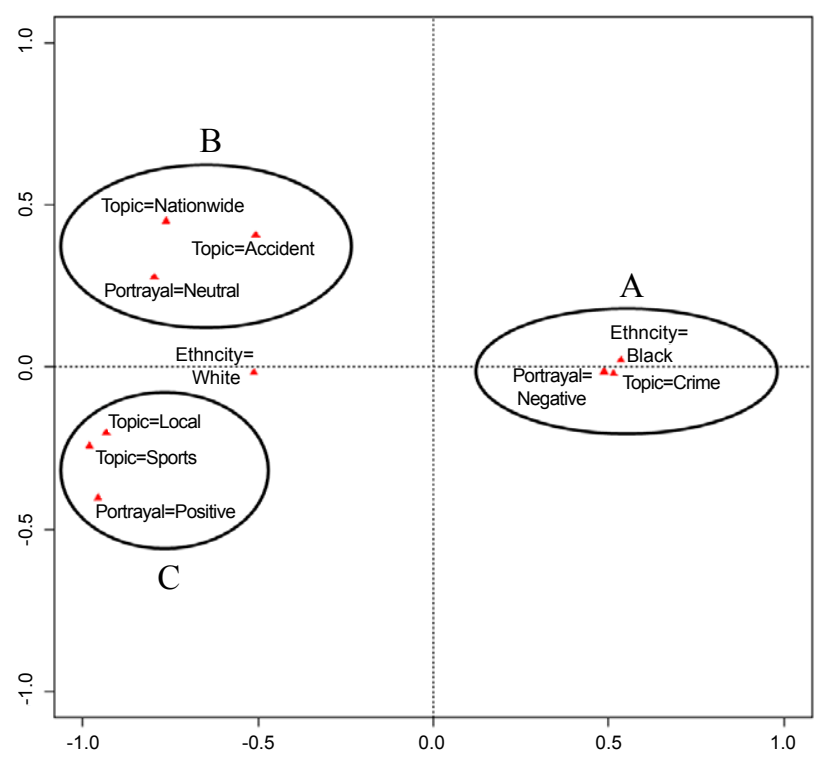

Figure 3: September 2012 through November 2012 lead news story correspondence analysis depicts statistical relationships and similarities among lead stories based on either story topic, ethnicity of the primary subject, or portrayal of that subject. Statistical clusters are represented by the letters $A, B$ and $C$. Cluster A contains lead news stories with Black males, negative either Nationwide, or Accident categories with a neutral portrayal. Cluster C contains lead news stories that were either about Local or Sports news, or those with a positive portrayal.

\begin{tabular}{|c|c|c|c|c|}
\hline $\begin{array}{c}\text { Correspondence Analysis } \\
\text { Category }\end{array}$ & Positive & Neutral & Negative & Inertia Values \\
\hline Accident & 0 & 5 & 4 & 0.112160 \\
\hline Crime & 2 & 4 & 111 & 0.082618 \\
\hline Local & 14 & 14 & 3 & 0.128490 \\
\hline Nationwide & 3 & 15 & 1 & 0.122102 \\
\hline Sports & 6 & 6 & 1 & 0.120479 \\
\hline Positive & 25 & 0 & 0 & 0.133634 \\
\hline Neutral & 0 & 44 & 0 & 0.126980 \\
\hline Negative & 0 & 0 & 120 & 0.077311 \\
\hline Black & 3 & 10 & 79 & 0.084976 \\
\hline White & 22 & 34 & 41 & 0.081535 \\
\hline
\end{tabular}

Table 3: Distribution of lead news stories for September through November 2012 by correspondence analysis categories and portrayal. Inertia values are included from the correspondence analysis.

to be stories that were purely factual. The subjects of these stories were more likely to be White males and were more likely to be portrayed in a neutral or positive way. For example, a lead story about a vehicular accident in Omaha that created lane closures along a primary roadway would not necessarily have a portrayal associated with it. The primary purpose of such a story would be informing motorists of why there were delays in the area.

Lead news stories within Cluster $\mathrm{C}$ were also similar as they were either stories about Local or Sports, or had an overall positive portrayal. An example of such a local story could be one that discussed holiday preparations at a local business. A sports example could be celebrating a player's performance during the regular season thus far. Lead stories in this statistical cluster would tend to portray the subjects in a positive manner compared to lead stories about crime.

The top (lead) stories with Whites as the primary story subject fell between Clusters B and C. This statistical placement shows that stories with White males either fell somewhere between a positive or a neutral portrayal. It is important to note that the placement of lead stories involving White males is dramatically different from that for lead stories involving Black males in Cluster A. This result from the correspondence analysis statistically supports the conclusion that Black males are disproportionately portrayed in negative ways in television lead news stories.

The relationships and clusters shown by the correspondence analysis provided an objective method to support the initial findings that Black males overwhelmingly appear in lead news stories about crime and that they are portrayed negatively. It is important to note that crime was not the only story topic with negative portrayals, though it was the most abundant (Table 3). While the numbers and percentages alone are interesting, the statistical clusters provide credibility. The correspondence analysis results are noteworthy as it provides a way to compare ethnicity to the negative portrayal of criminal activity. A clear association exists in this particular data set among news stories pertaining to criminal activity, those with Black males as the primary subject, and those with negative portrayals. While it is important to caution that these findings only were significant for the data set used in the study, the application of these methods to a broader temporal scale in addition to other media markets may yield worthwhile discussion regarding how media portrayals of both criminal activities and certain ethnic groups may be affecting society.

\section{Summary and Conclusions}

This study was designed to compare how the Omaha, Nebraska, television news stations' lead news stories represent Black versus White males to the extent to which race is associated with law-breaking activity. A close assessment of the stations' lead or big story of the day revealed that Black males in Omaha are depicted as criminals close to three times more often as White males. These findings appear to mirror other research that has shown that Blacks in general are overrepresented by the media in news of crime. It's clear that Black males will appear more frequently than White males as perpetrators and felons as depicted in the lead story in local television newscast. Also Black males in Omaha are overrepresented in television news lead stories as lawbreakers in comparison to official crime data and population demographics.

One could conclude that perhaps "modern racism" is alive and well in newsrooms all across the country, including Omaha, Nebraska. The argument could be made that newsrooms are not intentionally portraying Black men in a more negative light in their lead stories than they do White males, it may be more of a case of "business as usual." However, the question that must be addressed is whether this is just in Omaha or is this nation-wide? Is it only in newsrooms or are newsrooms just reflecting societies? Has Willie Horton become the standard image of crime, a black man pictured in an unflattering mug shot? Industry annual surveys of the racial make-up of television newsrooms shows little to no improvement in the number of minorities in leadership/ management roles [42]. It's believed that if more Blacks were hired as News Directors or even producers, perhaps that could lead to more diversity in general as well as more sensitivity in handling stories about different ethnicities [43].

The content analysis we presented revealed that during the study period, crime-related news stories topped the charts as the most frequent lead story. Crime-related stories accounted for more than $60 \%$ of all lead news stories. Black males were the primary story subject in $69 \%$ of all crime-related news stories. The arrest record data for Omaha 
Citation: Creighton TT, Walker CL, Anderson MR (2014) Coverage of Black versus White Males in Local Television News Lead Stories. J Mass Communicat Journalism 4: 216. doi:10.4172/2165-7912.1000216

Page 6 of 7

show that Black males accounted for only $31 \%$ of the arrests during the same period. Further investigation of the population demographics shows Omaha's population is approximately $14 \%$ Black. These results show an inconsistency and misrepresentation of the criminal activity within the city. The majority of the population and of people arrested is White; however, the majority of the crime-related media stories depict Blacks as perpetrators of crime.

The statistical groups derived from the correspondence analysis further suggest a misrepresentation of character based on ethnicity. Most of the lead news stories with a Black male were associated with either some type of criminal activity, a negative portrayal, or both. Stories with White males as the primary subject tended to be portrayed in either a positive or neutral manner in comparison. These findings suggest that media agencies may wish to evaluate how they portray events that occur within their viewing area. The media are a powerful tool and misrepresentation of social activity may only further stereotypes and ethnic bias.

Future investigation of the Omaha, Nebraska, television news media over a longer time period may develop additional insights about the portrayals of ethnic groups. Also, these methods may be applied to any metropolitan area's viewing market. It is important to consider these relatively smaller markets, though, as significant work has already been completed for more famous metropolitan viewing areas such as New York and Chicago. This work may eventually serve as guidance for news directors to caution their staff regarding the portrayal of criminal activity and ethnic groups. Further, it will enlighten society to always reconsider how information is presented whether it is through mainstream media or other avenues independent of the size of the media market.

\section{Acknowledgement}

The authors would like to thank the College of Journalism and Mass Communications (CoJMC) for its support. This project would not have been possible without CoJMC's purchase of the news broadcasts from Universal Information Services, a company that provides news monitoring. In addition, we thank the decoders who meticulously went through all of the broadcasts and classified each lead story. The researchers also thank Dr. John Bender and the anonymous reviewers for their constructive commentary and editorial assistance with this paper.

\section{References}

1. Ghosh P (2014) Omaha, Nebraska: The Most Dangerous Place in America for Blacks.

2. The 2012 Statistical Abstract (2012) U.S. Census Bureau

3. Bureau of Labor Statistics (2004) American Time Use Survey.

4. Dixon T (2007) Black Criminals and White officers: The effects of racially misrepresenting law breakers and law defenders on television news. Media Psychology 10: 270-291.

5. Entman R (1992) Blacks in the News: Television, Modern Racism and Cultural Change. Journalism and Mass Communication Quarterly 69: 341-361.

6. Entman R (1994) Blacks in News: Television, Modern Racism and Cultura Change.

7. Chiricos T, Eschholz S (2002) The Racial and Ethnic Typification of Crime and the Criminal typification of Race and Ethnicity in Local Television News. Journal of Research in Crime and Delinquency 39: 400-420.

8. McConahay J (1986) Modern Racism, Ambivalence and the Modern Racism Scale. New York Academic Press.

9. Sears D (1988) Symbolic Racism. New York Plenum

10. Barak G (1994) Between the Waves: Mass-Mediated Themes of Crime and Justice. Social Justice 21: 133-47.
11. Entman RM (1990) Modern Racism and the Images of Blacks in Local Television News. Critical Studies in Mass Communications 7: 332-45.

12. Dixon T, Linz D (2000) Overrepresentation and underrepresentation of African Americans and Latinos as lawbreakers on television news. Journal of Communication 50: 131-154.

13. Barlow M, Barlow D (1993) Cultural diversity Training in Criminal Justice: A Progressive Or Conservative Reform? Social Justice/Global Options 20: 69-84.

14. Behr RL (2001) Television News, Real-World Cues, and Changes in the Pulbic Agenda. Public Opinion Quarterly 49: 38-57

15. Gans HJ (1980) Deciding what's news: A study of CBS Evening News, NBC Nightly News, Newsweek, and Time. New York Vintage Books.

16. Hackett R (1984) Decline of a paradigm? Bias and objectivity in news media studies. Critical Studies in Mass Communication 1: 229-259.

17. Barlow M, Barlow D, Chiricos T (1995) Economic Conditions and Ideologies of Crime in the Media: A Content Analysis of Crime News. Crime \& Delinquency 41: 3-19.

18. Dixon T (2006) Psychological Reactions to Crime News Portrayals of Black Criminals: Understanding the Moderating Roles of Prior News Viewing and Stereotype Endorsement. Communication Monographs 73: 162-187.

19. Entman RM (2007) Framing Bias: Media in the Distribution of Power. Journal of Communication 57: 163-173.

20. Behr R, lyengar S (1985) Television News, Real-World Cues, and Changes in the Public Agenda. Public Opinion Quarterly 49: 38-57.

21. Olmstead K, Jurkowitz M, Mitchell A, Enda J (2013) How Americans Get TV News at Home, Pew Research Center Journalism Project.

22. Nielsen ratings (2013) Poynter

23. Russell K (1998) The Color of Crime: Racial Hoaxes, White Fear, Black Protectionism, Police Harassment and Other Macroaggressions. New York University Press, New York.

24. Tonry M (1996) Malign Neglect-Race, Crime, and Punishment in America. Oxford University Press, New York.

25. Roberts DE (1993) Crime, Race and Reproduction. Tulane Law Rev 67: 19451977.

26. Beckett K, Sasson T (2000) The Politics of Injustice: Crime and Punishment in America. SAGE Publications.

27. Cauchon D (1993) Sentences for Crack Called Racist. USA Today.

28. Dixon T, Azocar C, Casas M (2003) The portrayal of race and crime on television network news. Journal of Broadcasting and Electronics Media 47: 498-523.

29. Bjornstrom ES, Kaufman R, Slater M (2010) Race and Ethnic Representations of Lawbreakers ad Victims in Crime News: A National Study of Television. Soc Probl 57: 269-293.

30. Gibbs J (1988) Young, Black, and male in America: An endangered species Aubum House Publishing Company.

31. Auerbach J (2000) Improving health: It doesn't take a revolution. Health and Social inequality. Washinton, DC: Kellogg Foundation.

32. Whiting G (2006) From At Risk to At Promise: Developing Scholar Identies Among Black Males. Joural of Secondary Gifted Education 17: 222-229.

33. Noguera $P$ (1997) Responding to the Crisis Confronting Black Youth: Providing Support Without Furthering Marginalization. In Motion Magazine: Education Rights.

34. Spivak H, Prothrow-Stith D, Hausman, AJ (1988) Dying is no accident Adolescents, violence, and intentional injury. Pediatr Clin North Am 35: 1339 1347.

35. Leach L (2011) African American Images in the Media. California Community College, Mass Communications. A Slide Presentation.

36. Media Market Research: Media Consumption Trends Among Black Men (2011) The Opportunity Agenda.

37. Entman R (2000) Violence and Stereotypes, and African Americans in the News. In The Black image in the White mind: Media and race in America Chicago: University of Chicago Press. 
Citation: Creighton TT, Walker CL, Anderson MR (2014) Coverage of Black versus White Males in Local Television News Lead Stories. J Mass Communicat Journalism 4: 216. doi:10.4172/2165-7912.1000216

Page 7 of 7

38. Entman RM, Rojecki A (2000) The Entman-Rojecki Index of Race and the Media.

39. Nenadic O, Greenacre M (2007) Correspondence analysis in R, with two-and three-dimensional graphics: The ca package. Journal of Statistical Software 20: $1-13$.

40. Butke P, Sheridan SC (2010) An Analysis of the Relationship between Weather and Aggressive Crime in Cleveland, Ohio. Wea Climate Soc 2: 127-139.

41. Gamble JL, Hess JJ (2012) Temperature and violent crime in Dallas, Texas: relationships and implications of climate change. West J Emerg Med. 13: 239248.

42. Noguera $P$ (1996) Responding to The Crisis Confronting Black Youth: Providing Support Without Furthering Marginalization. Journal of Negro Education 65: 219-236.

43. Rivas-Rodriquez M (2004) Minority Journalists' Perceptions of the Impact of Minority Executives. Howard Journal of Communications 15: 39-55.

44. Douglas County arrest data (2014) Nebraska Commission on Law Enforcement and Criminal Justice, Omaha. 